\title{
Effect of sulcular green tea extract irrigation on experimental rabbit's gingivitis (A histopathological study)
}

\begin{abstract}
Dilyar Ahmed Baban (1)
\section{ABSTRACT}

Background and objective: Considering the antioxidant, anti-inflammatory, and antimicrobial properties of green tea, this study aimed to evaluate the histopathological effect of the sulcular irrigation of green tea extract in the treatment of experimental gingivitis in rabbit.

Materials and methods: For this experimental study, 45 male rabbits, separated in two groups, control non- irrigated group (5rabbits) and study group (40 rabbits), gingivitis induced by ligatures was packed subgingivally in the lower right central incisors of the experimental group for seven days. Then, the animals were randomly designated to two irrigated groups (20 rabbits for each) with $50 \mu 1 / \mathrm{kg}$ of distilled water and $5 \%$ green tea extract once daily for seven days starting from the day of ligature removal respectively. Specimens have taken at 1,3,7, and 14 days for light microscopical evaluation of inflammatory cellular infiltration.

Results: Regarding study group (5\% of green tea extract), results demonstrated a significant reduction in the mean values of inflammatory cell counts within three days $(\mathrm{P} \leq 0.05)$ to reach the amount of control group within seven days $(\mathrm{P}>0.05)$. A highly significant difference was detected between control group and study group sprayed with distilled water during all healing periods $(\mathrm{P} \leq 0.05)$. Histological examination showed that the resolution of gingival inflammation, re-epithelization, and tissue healing were achieved much quicker in the group of gingival sulcular irrigation with $5 \%$ green tea extract.

Conclusions: In this experimental study, the histopathological analysis demonstrated that the use of 5\% extract of green tea as gingival sulcular irrigation might fasten healing after the induction of gingivitis.
\end{abstract}

Keywords: green tea, animal model, gingival sulcular irrigation, experimental gingivitis. (Received: 25/10/2019; Accepted: $30 / 12 / 2019)$

\section{INTRODUCTION}

Animal models have an essential role in the generation of new knowledge in medical sciences, including periodontology. These innovative models have distinct advantages because they can reproduce in vivo cellular characteristics and reactions that occur in humans. Animal models in periodontal disease are particularly important in the development of the scientific basis for understanding the pathological processes. ${ }^{(1)}$ Gingivitis, as the multifactorial disease, is mainly derived by the interaction between invasions of causative bacteria and host immune response of varying degrees. ${ }^{(2)}$ Plaque induced gingivitis is the most common form of gingivitis and is induced by accumulation of microbial plaque containing more than 300 types of bacterial species ${ }^{(3)}$ and characterized by gingival redness and edema. ${ }^{(4)}$ Gingivitis is commonly painless which rarely leads to spontaneous bleeding, and is often described by subtle clinical changes, resulting in most patients being unaware of the disease or unable to recognize it. ${ }^{(5)}$ Periodontal diseases are one of the oldest and most prevalent illnesses known to humanity. As long back as 4000 years ago,

\footnotetext{
(1) Lecturer, Periodontology, College of Dentistry, Hawler
} Medical University, Erbil, Iraq
Green tea is abundant in polyphenols especially catechins, which contribute up to $30 \%$ of the dry leaf weight. Catechins include free catechins like catechins, gallocatechin, epicatechin and epigallocatechin and gallolyl catechins like epicatechin gallate, epigallocatechin gallate (EGCg), catechin gallate and gallocatechin gallate. ${ }^{(7)}$ Green tea exhibits antioxidant effects on the reactive oxygen species component, which plays an essential role in periodontal destruction. Coimbra et al., ${ }^{(8)}$ illustrated a significant decrease in lipid peroxidation products in the serum of green tea drinkers. They suggested that drinking green tea reduced the development or enhancement of oxidative stress thereby protecting the individual against oxidative stress diseases. A modest inverse association between the intake of green tea and periodontal disease has also shown, and the authors suggested that the application of concentrated green tea components, such as catechin may have a more beneficial effect on the periodontal condition. ${ }^{(9)}$ With one such an attempt, the present research was designed to evaluate the effectiveness of $50 \mu \mathrm{L} / \mathrm{kg}$ of $5 \%$ green tea extract ${ }^{(10)}$ sprinkled in the gingival sulcus to arrest the gingival inflammation induced by plaque accumulation in experimental gingivitis in rabbits by using a silk ligature around the lower central incisor. 


\section{MATERIAL AND METHODS}

Rabbits and housing: Forty-five healthy male rabbits were used in the study, aged about 810 months, weighing $1-1.3 \mathrm{~kg}$ and cared in the animal house of College of Medicine, Hawler Medical University, Erbil/ Iraq by the ethical principles of animal experimentation. They have maintained on a 12-hour light/dark cycle at $20 \pm$ $5^{\circ} \mathrm{C}$ and $20 \%-25 \%$ humidity. The research project has approved by the Research Ethics Committee at the College of Dentistry, Hawler Medical University.

Preparation of plant extract: An aqueous extraction of dry green tea has prepared by using five grams of dried green tea (Camellia Sinensis) in $100 \mathrm{ml}$ distilled water, heated to a temperature of $160 \mathrm{~F}^{\circ} / 69 \mathrm{C}^{\circ}$, and then steeped for 2 minutes. The decoction was filtered with filter paper and allowed to cool at room temperature. ${ }^{(11)}$

\section{Induction of experimental gingivitis: The} rabbits in the study groups (40 animals) were anesthetized by intraperitoneal administration of $4 \mathrm{mg} / \mathrm{kg}$ xylazine plus $40 \mathrm{mg} / \mathrm{kg}$ ketamine $\mathrm{HCL}^{(12)}$ and placed on a proper operating table, which allowed open-mouth maintenance of the rabbits to facilitate access to the teeth. Gingivitis has produced by a ligature of $4 / 0$ non resorbable sterile thread silk placed around the cervix of the lower right central incisor for each animal and kept for seven days. The rope was knotted on the lingual side so that it remained subgingivally on the labial side and supragingival on the lingual side. The animals were switched to a soft diet, consisting of commercial food biscuits soaked in warm water for 10 min and then drained. ${ }^{(13)}$ Daily we performed ligatures control and checking, and if any had been lost or become loose, it would be replaced. This ligature was acted as a gingival irritant for eight days and promoted the accumulation of plaque and subsequent development of gingivitis. A periodontal evaluation was performed for the lower right central incisor by a University of North Carolina (UNC) periodontal probe $(15 \mathrm{~mm})$ to determine to bleed upon probing (BOP) at four sites: distobuccal, buccal, mesiobuccal, and lingual. ${ }^{(14)}$

Experimental design: A total of 45 males rabbits were divided randomly into two groups as follow:

The control group (5 rabbits): Animals received healthy food and no ligatures, the normal gingival sulcus of non- irrigated and free from experimental gingivitis (baseline apparently healthy).

Study groups (40 animals): After induction of gingivitis, the animals have randomly divided into two groups (20 animals each) according to type of materials used in sulcus irrigation, distilled water gingival sulcus irrigated group and $5 \%$ green tea extract gingival sulcus irrigated group. In the distilled water treated group, a volume of distilled water $(50 \mu \mathrm{L} / \mathrm{kg} \mathrm{B}$.W) equal to green tea extract $(50 \mu \mathrm{L} / \mathrm{kg} \mathrm{B}$.W of $5 \%$ green tea extract) have used.

Sulcular gingival irrigation was performed into the mid- labial area of the gingival sulcus of the lower right central incisor for once daily for seven days starting from the day of ligature removal. The depth of needle penetration was measured by adjusted stopper $5 \mathrm{~mm}$ from the tip of the needle; the solution was injected slowly and carefully throughout ten seconds. ${ }^{(10)}$ For distilled water gingival sulcus irrigated group and 5\% green tea extract gingival sulcus irrigated group, five animals for each healing interval $(1,3,7$ and 14 days), were sacrificed and studied.

Tissue processing: At day 1,3,7, and 14, all the animals were sacrificed ( 5 animals each) and the mandible from each animal was taken, fixed in $10 \%$ neutral buffered formalin, decalcified in $37 \%$ hydrochloric acid, processed, sectioned in labio-lingual direction, and stained with hematoxylin and eosin. Two representative tissue sections from each block were analyzed to examine the gingiva on the labial side of the tooth. Analysis of the intensity of the inflammatory reaction performed by assessing the number of inflammatory cells in histological sections (H\&E stained), for each animal and in four microscopic fields under $\mathrm{x} 40$ magnification and the gingival inflammatory scores were graded as follows ${ }^{(15)}$ :

Score 0: Absence of or only discrete inflammatory cellular infiltration (from 0 to $<5$ cells)

Score 1: Mild inflammatory cellular infiltration (5 to less than 25 cells).

Score 2: Moderate inflammatory cellular infiltration (25 to less than 125 cells).

Score 3: Severe inflammatory cellular infiltration (more or equal to 125 cells). All analysis was blind to the origin of the sample.

Statistical analysis: Data were analyzed using the statistical package for social science (SPSS, Statistical for Windows, version 20.0 Armonk, NY: IBM Corp). All data were expressed using 
descriptive statistics like the mean and standard deviation $\pm(\mathrm{SD})$ and statistical analysis using Paired sample t-test. $P$-value of $\leq 0.05$ was considered statistically significant.

\section{RESULTS}

Animals showed no apparent signs of systemic illness throughout the study. On the third day (after surgical placement of the silk ligature around the cervix of the lower right central incisor), clinical periodontal evaluation revealed the presence of little gingival inflammation; gingival tissue began to lose its regular aspect and structure. The gingival color changed from pink to intense red. Plaque accumulation was detected around the ligated silk thread including the dentogingival junction. The changes observed were accentuated from the third day until seven days from the induction of gingivitis.

\section{Descriptive histology \\ Control group}

Histological analysis of apparently healthy gingiva revealed mature squamous cell epithelium with subepithelial connective tissue region made of well-arranged bundles of collagen fibers, fibroblasts, and few inflammatory cells infiltrated the area. The dentogingival tissue did not reveal any signs of inflammatory response in the connective tissue (Figure 1).

\section{Study group \\ Distilled water gingival sulcus irrigation group}

On day 1

After one day of induction of gingivitis, the histological view of dentogingival tissues of group B1, shown moderate chronic inflammatory cell accumulation along the gingival wall with ulcerative sulcular epithelium, highly vascularized connective tissue filled with $\mathrm{RBC}$ and destructive of collagen fiber (Figure 2).

On day 3

Histological findings at defect site of control group of 3 days duration shows parakeratinized oral epithelialization and scant inflammatory cells together with irregular arrangement of collagen fibers containing moderate chronic inflammatory cells mainly a few monocytes and small lymphocytes in a narrow zone at the epithelialconnective tissue interface with ulcerative sulcular epithelium, and destructive blood vessels (mild hemorrhage) (Figure 3).
On day 7

Histological section of dentogingival are showed parakeratinized oral epithelium with mild inflammatory reaction in the lamina propria directly below oral and sulcular epithelium, besides that there was ulceration of the superficial gingival tissue of sulcular epithelium due to the ligature (Figure 4).

On day 14

Histological sections showed mild inflammatory reactions in the lamina properia with irregularaligned new collagen fibers found in the interdental region of control group. However, inflammatory cells decreased, and a lot of fibroblasts were found with incomplete reepithelialization (Figure 5).

\section{$5 \%$ green tea extract irrigation group}

On day 1

Histological examination revealed moderate inflammatory response to irritation caused by ligature thread which induced significant gingival inflammation revealed abundant infiltration of inflammatory cells with slight fibroblastic activity and destructed blood vessels (mild bleeding) in the connective tissue supporting gingival epithelium. The histopathological aspect of the superficial gingival tissue in sulcular area revealed ulceration as affected by existence of the ligature (Figure 6).

On day 3

Histological section showed mild inflammatory response with scant chronic inflammatory cells among the gingival epithelial rete pegs and deep in connective tissue. In addition, there was loose fibrous connective tissue with signs of remodeling accompanied by active fibroblasts and reepithelialization (Figure 7).

On days 7-14

Histological section revealed no inflammatory response with sparsely scattered chronic inflammatory cells infiltration and complete epithelialization, formation of new blood vessels, and accumulation of irregular-aligned new collagen fibers. After 14 days duration, we observed no signs of inflammation in the connective tissue, dense collection of relatively well-aligned new collagen fibers, which indicated relatively complete healing of dentogingival region (Figures 8 and 9). 

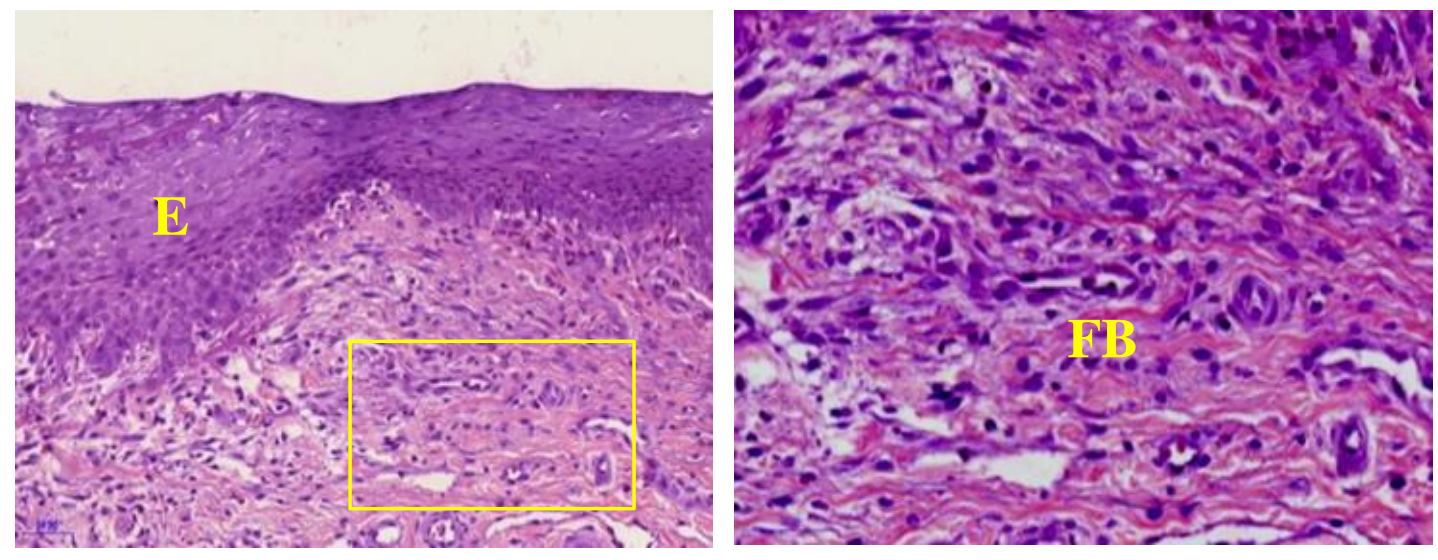

Figure 1: Histopathological findings belong to apparently normal gingiva (control group) in rabbit showing normal histology of dentogingival area epithelial $(\mathbf{E})$, fibrous connective tissue and fibroblasts (FB). H\&E x20, x40.
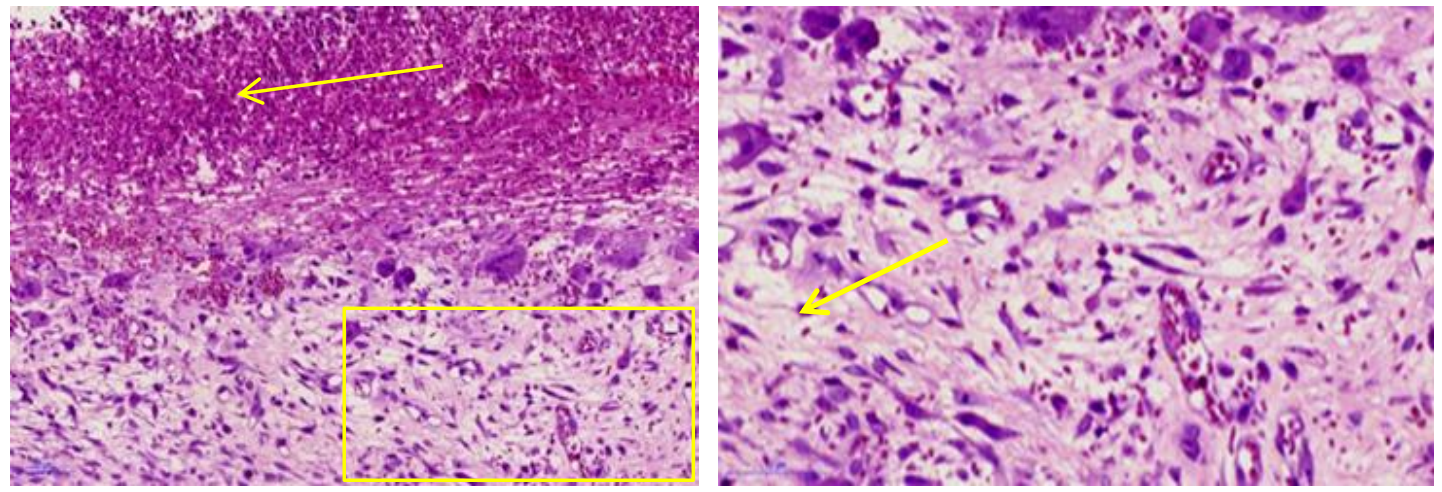

Figure 2: Microphotograph of study group treated with gingival sulcular irrigation of $50 \mu \mathrm{L} / \mathrm{kg}$ of distilled water after one day showing moderate diffuse inflammatory cell infiltration, ulceration of sulcular epithelium (arrows). H\&E x20, x40.
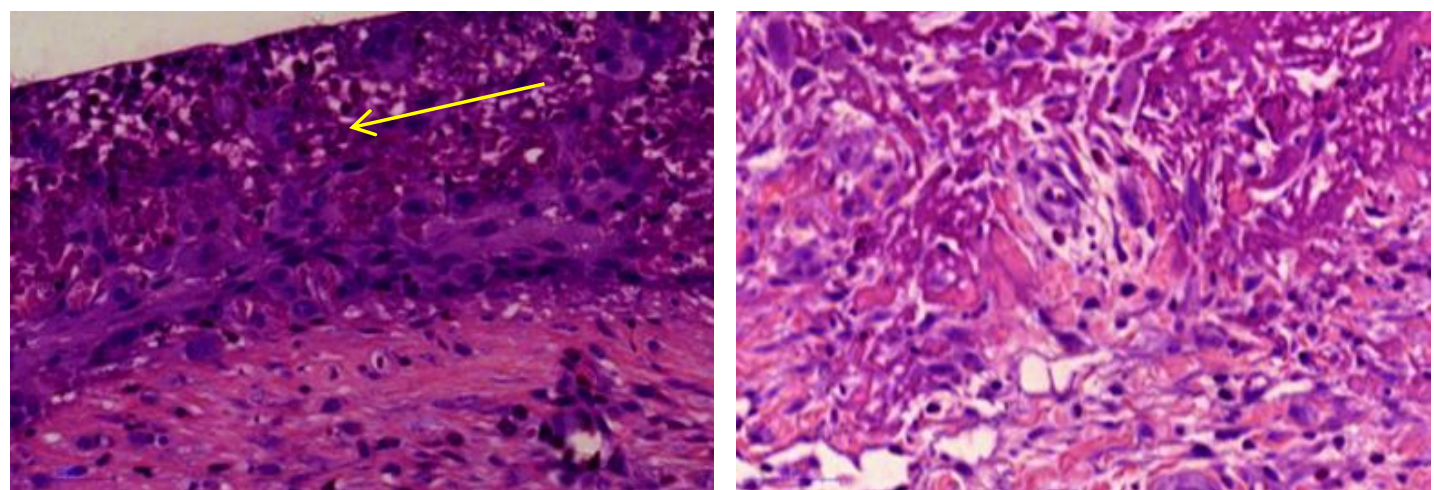

Figure 3: Microphotograph of study group treated with gingival sulcular irrigation of $50 \mu \mathrm{L} / \mathrm{kg}$ of distilled water after three days showing a moderate inflammatory reaction, ulcerative sulcular epithelium (arrow). H\&E x20, x40. 

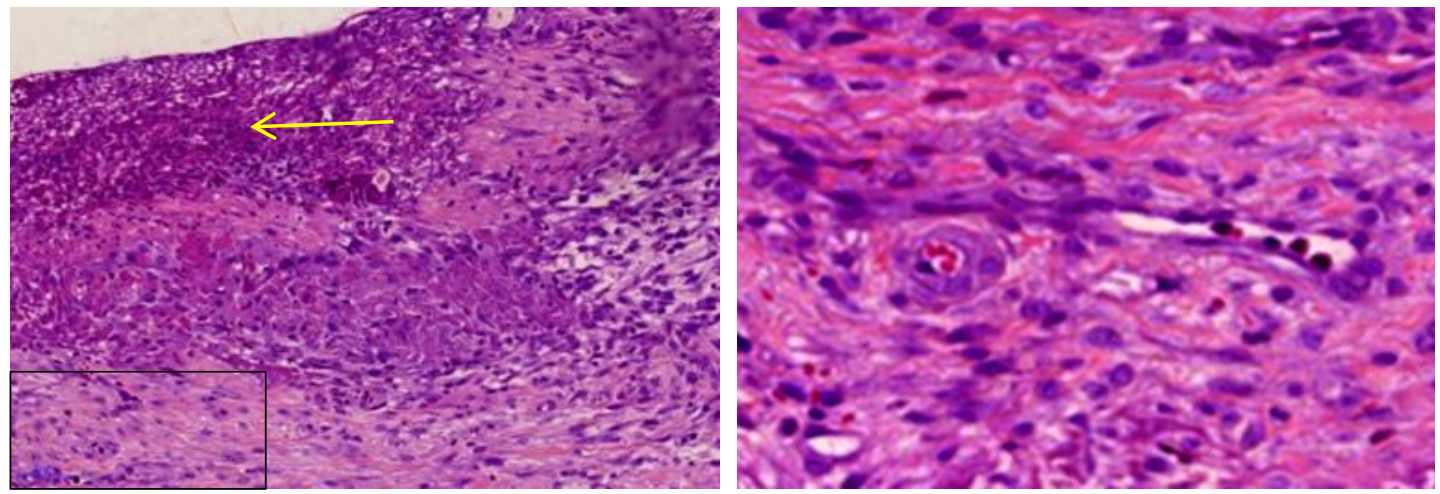

Figure 4: Microphotograph of study group treated with gingival sulcular irrigation of $50 \mu \mathrm{L} / \mathrm{kg}$ of distilled water after seven days showing mild inflammatory cell, ulcerative sulcular epithelium (arrow). H\&E x20, x40.
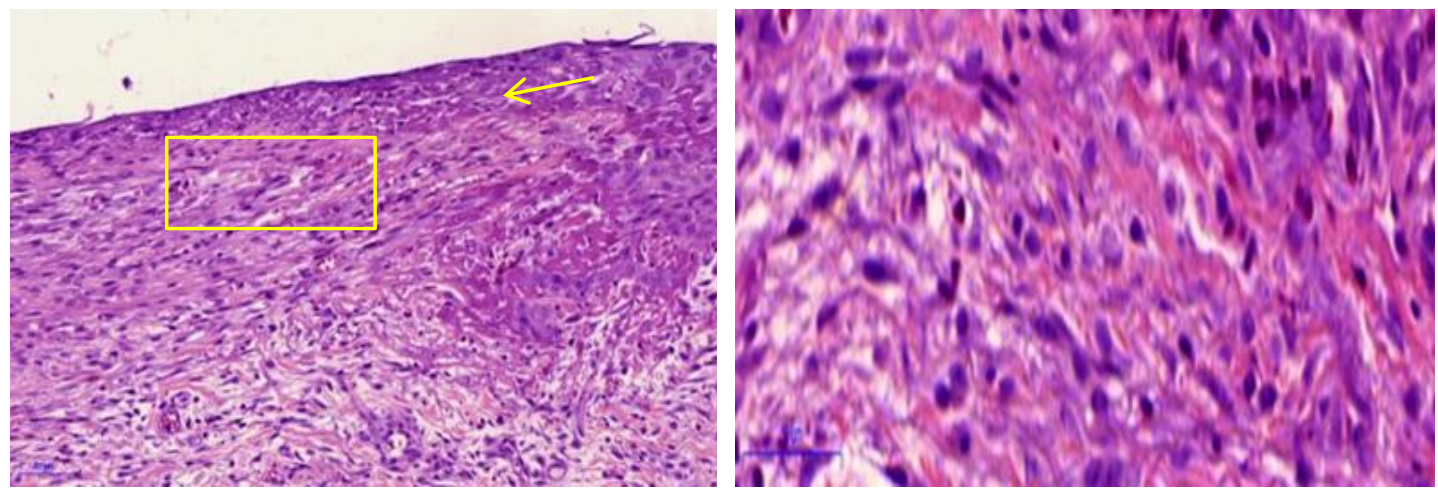

Figure 5: Microphotograph of study group treated with gingival sulcular irrigation of $50 \mu \mathrm{L} / \mathrm{kg}$ of distilled water after 14 days showing shows a mild inflammatory cell with still exhibited incomplete reepithelization (arrow). H\&E x20,x40
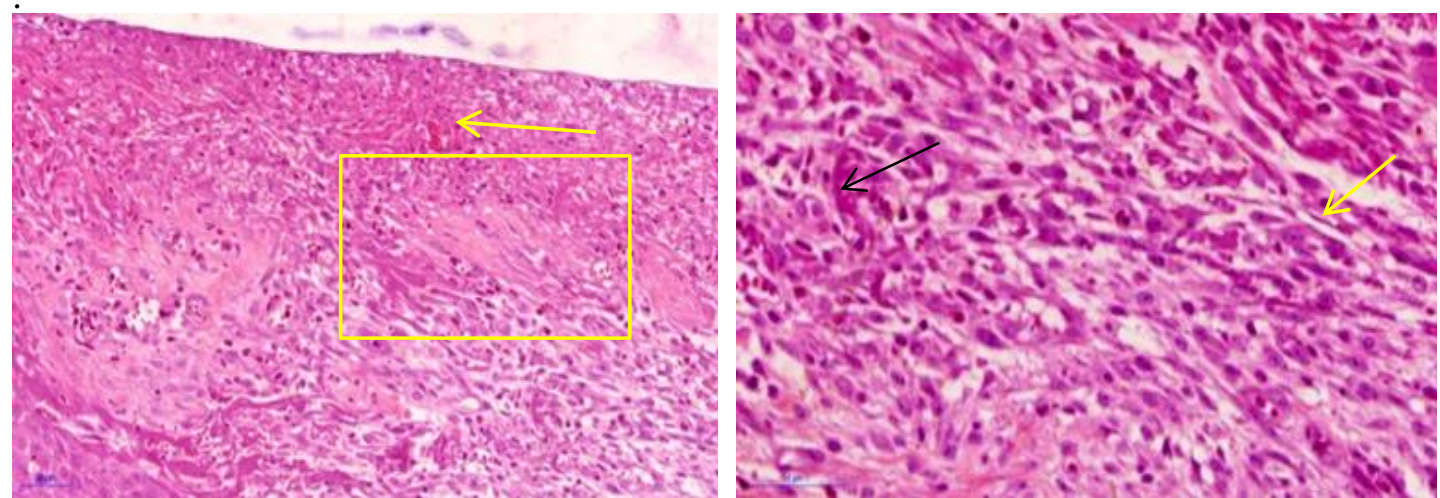

Figure 6: Microphotograph of study group treated with gingival sulcular irrigation of $50 \mu \mathrm{L} / \mathrm{kg}$ of $5 \%$ green tea extract after one day showing moderate inflammatory cell infiltration with slight fibroblastic activity, mild bleeding and ulcerative sulcular epithelium (arrows). H\&E x20, x40. 


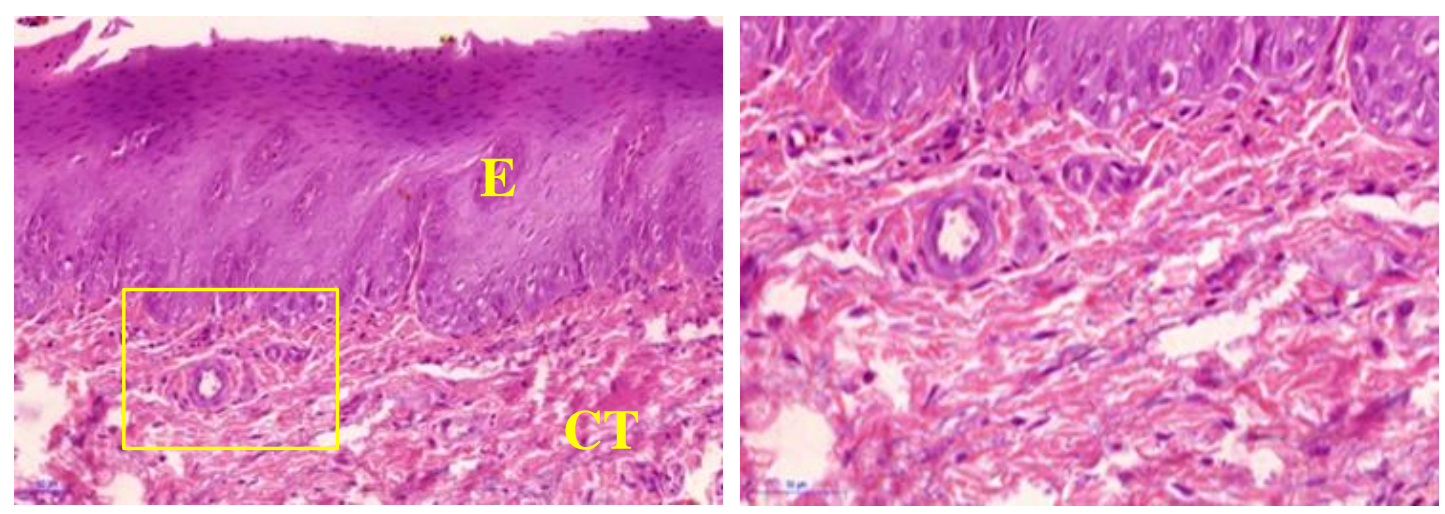

Figure: 7 Microphotograph of study group treated with gingival sulcular irrigation of $50 \mu \mathrm{L} / \mathrm{kg}$ of $5 \%$ green tea extract after three days showing a mild inflammatory reaction, no ulcerative epithelia (E) with remodeling fibrous connective tissue (CT). H\&Ex20, $x 40$.
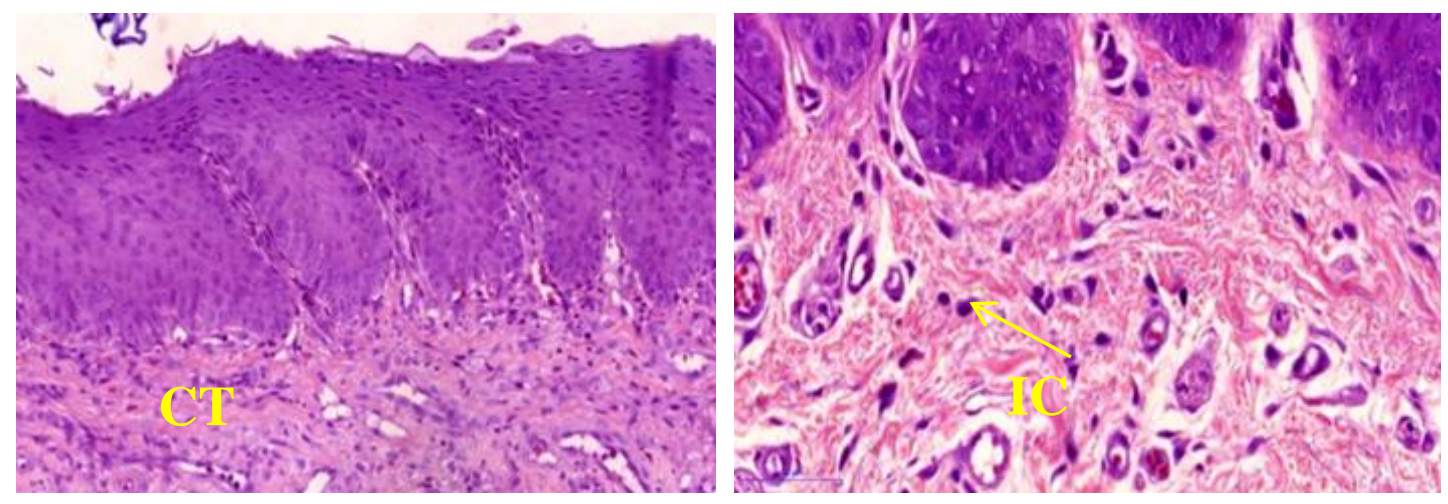

Figure 8: Microphotograph of study group treated with gingival sulcular irrigation of $50 \mu \mathrm{L} / \mathrm{kg}$ of $5 \%$ green tea extract after seven days showing fibrous connective tissue (CT), scarce number of inflammatory cells (IC) (arrow) and complete epithelization. . H\&E x20, x40.
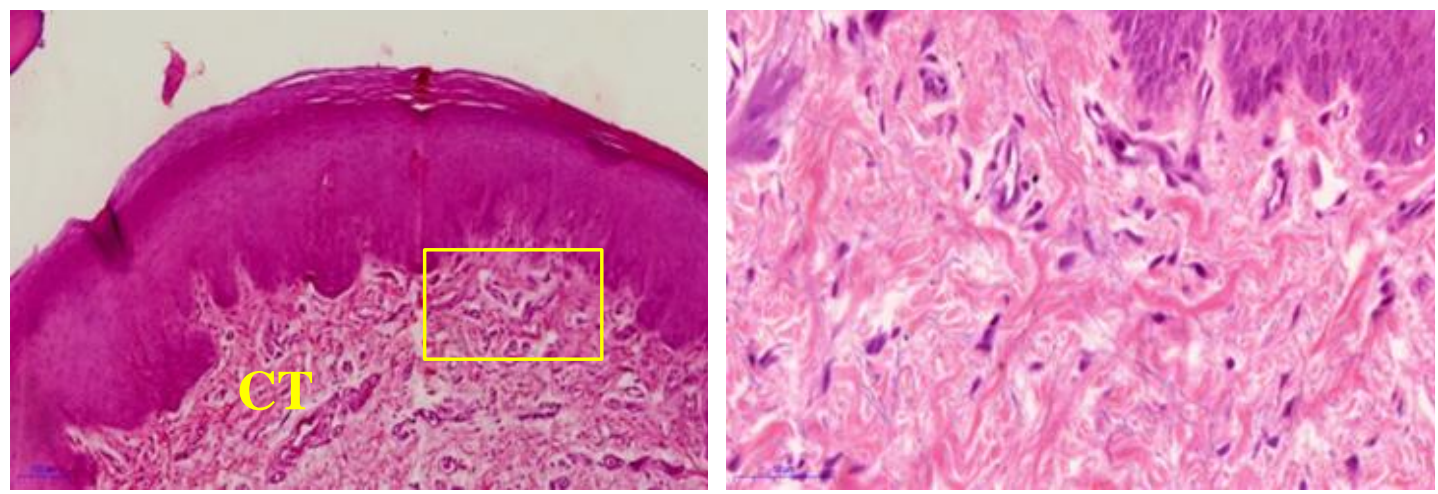

Figure 9: Microphotograph of study group treated with gingival sulcular irrigation of $50 \mu \mathrm{L} / \mathrm{kg}$ of $5 \%$ green tea extract after 14 days showing complete epithelization, dense fibrous connective tissue (CT). H\&E x20, x40.

Table 1 shows descriptive statistics of inflammatory cell count/ $\mathrm{mm}^{2}$ of control and study groups at different healing periods $(1,3,7$ and 14 days) at the gingival inflammatory site. The results of the present study showed a higher number of inflammatory cells for study group sprayed with distilled water than in study group inundated with $5 \%$ of green tea extract. Regarding study group ( $5 \%$ of green tea extract), the mean values of cell count were observed to decrease within three days to reach the amount of control group within seven days. A major significant difference was detected between control group and study group sprayed with distilled water during all healing periods, while no significant differences were observed between control group and study group sprayed with $5 \%$ of green tea extract at seven and 14 days. 
Table 1: Distribution of the observed inflammatory cells in different periods among the control group (healthy gingiva) and study groups irrigated with (distilled water and green tea extract).

\begin{tabular}{|c|c|c|c|}
\hline Day & Groups & $\begin{array}{c}\text { Number of inflammatory } \\
\text { cells }\end{array}$ & $P$-value \\
\hline \multirow{3}{*}{ Day 1} & $\begin{array}{c}\text { healthy gingiva } \\
\text { gingivitis/distilled water }\end{array}$ & $\begin{array}{c}3.8 \pm 1.30 \\
44.6 \pm 5.98\end{array}$ & .000 \\
\hline & $\begin{array}{c}\text { healthy gingiva } \\
\text { gingivitis/green tea }\end{array}$ & $\begin{array}{l}3.8 \pm 1.30 \\
40.0 \pm 3.60 \\
\end{array}$ & .000 \\
\hline & $\begin{array}{l}\text { gingivitis/ distilled water } \\
\text { gingivitis/green tea }\end{array}$ & $\begin{array}{l}44.6 \pm 5.98 \\
40.0 \pm 3.60\end{array}$ & .259 \\
\hline \multirow{3}{*}{ Day 3} & $\begin{array}{c}\text { healthy gingiva } \\
\text { gingivitis/ distilled water }\end{array}$ & $\begin{array}{c}3.8 \pm 1.30 \\
37.00 \pm 8.86\end{array}$ & .002 \\
\hline & $\begin{array}{c}\text { healthy gingiva } \\
\text { gingivitis/green tea }\end{array}$ & $\begin{array}{c}3.8 \pm 1.30 \\
17.80 \pm 5.63\end{array}$ & .005 \\
\hline & $\begin{array}{l}\text { gingivitis/ distilled water } \\
\text { gingivitis/green tea }\end{array}$ & $\begin{array}{l}37.00 \pm 8.86 \\
17.80 \pm 5.63\end{array}$ & .014 \\
\hline \multirow{3}{*}{ Day 7} & $\begin{array}{c}\text { healthy gingiva } \\
\text { gingivitis/ distilled water }\end{array}$ & $\begin{array}{c}3.8 \pm 1.30 \\
15.80 \pm 5.26\end{array}$ & .004 \\
\hline & $\begin{array}{c}\text { healthy gingiva } \\
\text { gingivitis/green tea }\end{array}$ & $\begin{array}{c}3.8 \pm 1.30 \\
3.60 \pm 1.140 \\
\end{array}$ & .799 \\
\hline & $\begin{array}{l}\text { gingivitis/ distilled water } \\
\text { gingivitis/green tea }\end{array}$ & $\begin{array}{l}15.80 \pm 5.26 \\
3.60 \pm 1.140\end{array}$ & .005 \\
\hline \multirow{3}{*}{ Day 14} & $\begin{array}{c}\text { healthy gingiva } \\
\text { gingivitis/ distilled water }\end{array}$ & $\begin{array}{c}3.8 \pm 1.30 \\
11.40 \pm 3.646\end{array}$ & .004 \\
\hline & $\begin{array}{c}\text { healthy gingiva } \\
\text { gingivitis/green tea }\end{array}$ & $\begin{array}{c}3.8 \pm 1.30 \\
2.60 \pm 1.516\end{array}$ & .145 \\
\hline & $\begin{array}{l}\text { gingivitis/ distilled water } \\
\text { gingivitis/green tea }\end{array}$ & $\begin{array}{c}11.40 \pm 3.646 \\
2.60 \pm 1.516\end{array}$ & .001 \\
\hline
\end{tabular}

\section{DISCUSSION}

Gingivitis is one of the most prevalent diseases in humans, and many studies have used experimental animals to investigate its pathogenesis. Ligature placement in the teeth has been proposed to obtain an experimental gingivitis condition more quickly than natural occurring gingivitis. ${ }^{(16)}$ In this study, we achieved a stage of periodontal disease consistent with moderate gingivitis. This type of gingivitis is similar to the level of periodontal disease identified in humans. The present study used 5\% of green tea extract irrigated in the gingival sulcus of rabbit's periodontium; related to its ability to accelerate the healing of experimental rabbit's gingivitis. Findings support the beneficial effect of green tea to improve inflammatory experimental gingivitis after one week of treatment.

Furthermore, improvement of gingival conditions in the control group is due to the positive effects of distilled water in increasing oral hygiene. The most prominent feature of distilled water irrigated group is continuation of moderate inflammatory reaction over one week. This attributes to, in periodontal inflammation, polymorph nuclear leucocytes (PMNs) produce reactive oxygen species (ROS) as the initial host defense against bacterial pathogens. ${ }^{(17)}$ However, excessive production of ROS has determinately an effect on the host defense system. ${ }^{(18)}$ In the present work, we have observed that healing repair is noticed by declining the inflammatory reaction after seven days of induction of gingivitis and irrigated by distilled water but remains through the experimentation. The actual mechanism for such reduction of inflammatory response would not explain clearly, but the following hypothesis may propose that PMNs and macrophage cells contain intracellular ascorbic acid concentrations that are 10-40 times higher than plasma. High ascorbic acid level achievable in leucocytes contributes to the ability of these cells to react to inflammatory stimuli. ${ }^{(19)}$

Green tea has been reported to be useful for the prevention of periodontal disease and the maintenance of oral health. Green tea has been found to decrease plaque formation in previous studies. $^{(9,20)}$ Green tea is reported to prevent gathering of bacteria and thereby to prevent plaque formation on teeth. ${ }^{(20)}$ Green tea has shown inhibitory effect on collagenolytic enzymes, thus preventing periodontal inflammation. Its catechin significantly reduces the expression of matrix 
metalloproteinase-9 in osteoblasts and also inhibits the formation of osteoclast. ${ }^{(21)}$ Tea catechins containing the galloyl radicals possess the ability to inhibit both eukaryotic and prokaryotic cell-derived collagenase, an enzyme that plays an essential role in the disruption of the collagen component in the gingival tissues of patients with periodontal disease. Green tea catechins have also been shown to inhibit protein tyrosine phosphatase in $P$. intermedia. ${ }^{(22)}$ Green tea can sequester metal ions and scavenge reactive oxygen species. Studies showed that green tea might decrease several proteins involved in inflammation, including lipogenase, cyclooxygenase, nitric oxide synthase, tumor necrosis factor- $\alpha$ and nuclear factor-kB (NFkB), to modulate inflammation associated signals. ${ }^{(23)}$ These results agree with those obtained in this study that there is an improvement in the healing process more seen in experimental gingivitis treated with a 5\% green tea group. The recovery is probably due to decreased collagenolytic activity and inhibitory effect on periodontal pathogens. However, in an experimental study performed on tea polyphenols in the form of sulculer irrigation on gingival inflammation over one-week period showed that the tea polyphenols might exert a positive influence on gingival inflammation. Histological review of tissue response showed that after administration of sulcular irrigation of $5 \%$ aqueous green tea extract there are marked degree of restoration and improvement of inflammatory reaction. This improvement might be explained by the fact that green tea is rich in polyphenols, but it also contains ascorbic acid (vitamin C), which could increase the green tea polyphenol antioxidant potential. ${ }^{(24,25)}$ This result agreed with almost all studies that recorded reactive oxygen species would appear to play a significant role in the pathogenesis of periodontal disease. (26) Morphometric analysis of gingival rabbit showed that all the changes in inflammatory reaction caused by the ligature irritant have significantly improved after administration of sulcular irrigation green tea extract. The reduction of inflammatory response indicated that a positive influence of green tea polyphenols on reduction of inflammatory response of the gingiva. ${ }^{(27)}$ The present study supported the previous study performed by Abdel-Raheem et al. ${ }^{(28)}$ who reported that green tea extract blocked cellular inflammatory process as indicated from alleviation of prevascular edema and reduction in mononuclear leucocytes inflammatory cells infiltration.

\section{CONCLUSIONS}

The results of the current study indicated that the use of natural antimicrobial agents might prevent the formation of biofilms and treated the gingival inflammation. In comparison with distilled water, green tea showed better effects and potency because of its active phenolic ingredients or other nutritional components. Histological findings revealed that $5 \%$ green tea extract as gingival sulcular irrigation in treatment of experimental model of gingivitis in rabbits might improve and fasten healing after the induction of gingivitis.

\section{ACKNOWLEDGEMENT}

The author would like to thank Dr. Saman Abdulla, Consultant histopathologist FRCPath (UK ) CCST histopath (RCPI- Ireland)- Hawler Medical University, and special thanks to Prof. Dr. Seta Arshak Sarkis- Uruk University, Iraq for help reading the slides.

\section{REFERENCES}

1- Graves DT, Kang J, Andriankaja O, Wada K, Rossa C Jr. Animal models to study host bacteria interactions involved in periodontitis. Front Oral Biol 2012;15:117-132.

2- Poosattar Bejeh Mir A. Focusing on periodontitis as a vasculopathy: The therapeutic possibilities from the perspective of a dentistry student. J Pharm Biomed Sci. 2011;13:1-5.

3- Newman MG, Takei HH, Klokkevold PR, Carranza FA: Carranza's clinical periodontology. $12^{\text {th }}$ ed. St Louis: W.B.Saunders Elsevier; 2015.

4- American Academy of Periodontology. The parameter on plaque-induced gingivitis. J Periodontol. 2000;71:851-852.

5- Blicher B, Joshipura K, Eke P. Validation of selfreported periodontal disease: a systematic review. J Dent Res. 2005;84:881-890.

6- Loe H. Periodontal diseases: A brief historical perspective. Periodontol. 1993;2:7-12.

7- Cabrera C, Artacho R, and Giménez R. Beneficial effects of green tea-A review. J Am Coll Nutr. 2006;25:79-89.

8- Coimbra S, Castro E, Rocha-Pereira P, Rebelo I, Rocha I, Santos-Silva S. The effect of green tea in oxidative stress. Clin Nutr. 2006;25:790-796.

9- Kushiyama M, Shimazaki Y, Murakami M, Yamashita Y. Relationship between intake of green tea and periodontal disease. J Periodontol. 2009;80:372-7.

10- Baban DA, Ibrahim LM, Waheeda NE. The effect of gingival sulcular injection of green tea extract. Biochemical, immunological and histopathological study on rabbit. 2013. PhD thesis, College of Dentistry, Hawler Medical University, Iraq.

11- Avwioro G, Lyiola S, Aghoghovwia B. Histological and biochemical markers of the liver of Wistar rats on 
subchronic oral administration of green tea. $\mathrm{N}$ Am J Med Sci. 2010; 2: 376-380.

12- Hedquist, P. Anaesthesia and analgesia for surgery in rabbits and rats: A comparison of the effects of different compounds. Ph.D. A thesis submitted to the Karolinska Institute, Stockholm Sweden. 2008.

13- Kornman KS, Holt SC, Robertson PB. The microbiology of ligature-induced periodontitis in the cynomolgus monkey. J Periodontal Res. 1981;16:363371.

14- Cappelli D, Holt SC, Singer RE, Pickrum HM, Ebersole JL. Effects of $0.12 \%$ chlorhexidine gluconate on experimental gingivitis in nonhuman primates: clinical and microbiological alterations. Oral Dis. 2000;6:124-131.

15- Accorinte M, Holland R, Reis A, Bortoluzzi M, Murates S. Union of mineral trioxide cement as a pulp capping agent in teeth. J Endod. 2008;34:1-6.

16- Giavedoni LD, Chen H, Hodara VL. Impact of mucosal inflammation on oral simian immunodeficiency virus transmission. J Virol. 2013;87:1750-1758.

17- Sculley DV and Langley-Evans SC. Salivary antioxidants and periodontal disease status. Proc Nutr Soc. 2002;61:137-143.

18- Das, S. and Vasudevan, D. Alcohol-induced oxidative stress. Life Sci. 2007;81:177-187.

19- Oberritter H, Glatthaar B, Moser U. Effect of functional stimulation on ascorbate content in phagocytes under physiological and pathological conditions. Int Arch Allergy Appl Immunol. 1986;81:46-50

20- Kaur H, Jain S, Kaur A. Comparative evaluation of the antiplaque effectiveness of green tea catechin mouthwash with chlorhexidine gluconate. J Indian Soc Periodontol. 2014;18:178-182.
21- Yun JH, Pang EK, Kim CS, Yoo YJ, Cho KS, Chai JK. Inhibitory effects of green tea polyphenol (-)epigallocatechin gallate on the expression of matrix metalloproteinase- 9 and the formation of osteoclasts. J Periodontal Res. 2004; 39:300-307.

22- Poyato-Ferrera M, Segura-Egea JJ, Bullón-Fernández P. Comparison of modified bass technique with normal toothbrushing practices for efficacy in supragingival plaque removal. Int J Dent Hyg. 2003;1:110-114.

23- Caveat MK, and Vollmer TR. Anti-inflammatory and anti-oxidative effects of the green tea polyphenol epigallocatechin gallate in human corneal epithelial cells. Mol Vis. 2011; 17:533-542.

24- Kim JH, Kang BH, Jeong JM. Antioxidant, antimutagenic, and chemopreventive activities of a phyto-extract mixture derived from various vegetables, fruits, and oriental herbs. Food Sci Biotechnol. 2003;12:631-638.

25- Hijazi MM, Khatoon N, Azmi MA, Rajput MT, Zaidi SI, Perveen R, Naqvi SN, Rashid M. Effects of Camellia Sinensis L. (green tea) extract on the body and testicular weight changes in adult Wister rat. Pak. J Pharm Sci. 2015;28:249-253.

26- Lakshmisree S, and Mythili R. Antioxidants in periodontal disease. Ind $\mathrm{J}$ Multidisciplinary Dent. 2011;1.

27- Krahwinkel T, Willershausen B. The effect of sugarfree green tea chew candies on the degree of inflammation of the gingiva. Eur $\mathrm{J}$ Med Res. 2000;5:463-467.

28- Abdel-Raheim MM, Enas AH, Khaled AE. Effect of green tea extract and vitamin $\mathrm{c}$ on oxidant or antioxidant. Indian J Clin Biochem. 2009;24:280-287.

خلفية واهداف البحث: الثاب الاخضرله خصائص عديده كمضاد للأكسدة ، كمضاد للالتهابات وايضا كمضادة للميكروبات ، هدفت هذه الدر اسة من خلال دراسه التشريح النسيجي تقييم تأثير الغسل بمستخلص الثشاي الأخضر في علاج التهاب اللثة التجريبي في الأر انب .

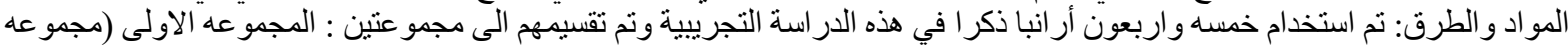

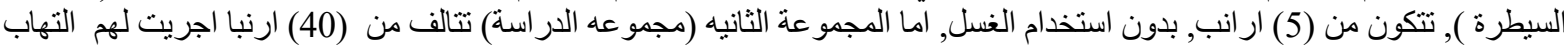

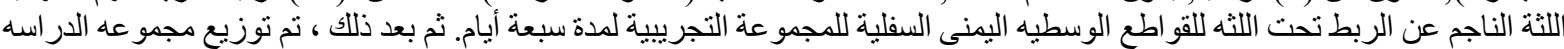

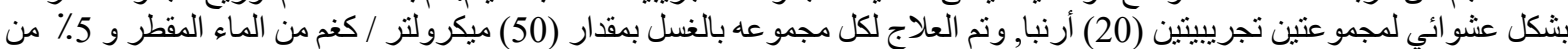

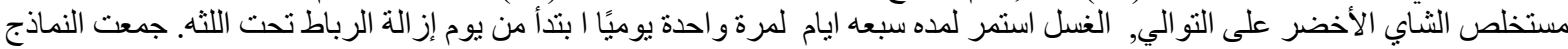

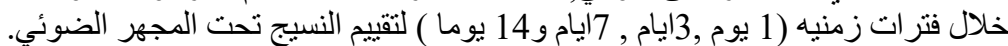
النتائج: أظهر الفحص النسيجي أن السيطره على على التهاب اللثنه مع اعاده تكوين النسيج الطلائي وشفاء الأنسجة بشكل كبير قد تحقق بشكل

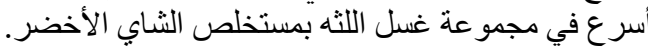

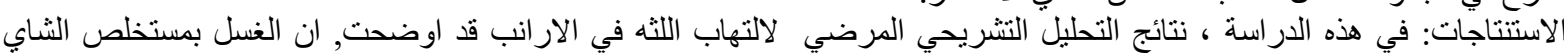

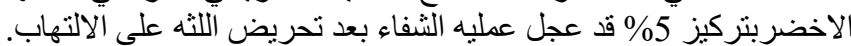

